\title{
FAILURE OF $\epsilon$-AMINOCAPROIC ACID IN THE TREATMENT OF SCLERODERMA
}

\author{
BY \\ A. P. HALL AND J. T. SCOTT \\ Department of Medicine, Postgraduate Medical School, London
}

In recent years $\epsilon$-aminocaproic acid (EACA) has been introduced to clinical medicine as an antifibrinolytic agent (Sherry, Fletcher, Alkjaersig, and Sawyer, 1959) and has been used in the treatment of a variety of haemorrhagic disorders (Sweeney, 1965).

Rotstein, Gilbert, and Estrin (1963) commented favourably on its therapeutic effect in progressive systemic sclerosis (scleroderma) and later (Rotstein, Reiss, Lauriello, and Bourel, 1965) reported that 21 of 33 cases showed a fair to excellent response. Its beneficial effect was attributed to the hypothesis that the pathological changes in scleroderma were caused by breakdown products of fibrinolysis, which was inhibited by EACA.

The value of therapy in scleroderma is difficult to assess because of the variable course which the disease can run. It therefore seemed desirable to obtain further information about the new drug. This paper presents briefly our experience with EACA in eight patients. Six had classical scleroderma; one (Case 4) had dermatomyositis with calcinosis and sclerodactyly; and one (Case 8) had Werner's syndrome with sclerodermatous changes developing in the legs.

\section{Methods of Assessment}

Symptoms were carefully recorded before, during, and after therapy. Objective changes were noted, supplemented when indicated by clinical photography.

Strength of grip was tested with a standardized rubber bag attached to a mercury sphygmomanometer, filled with air to an initial pressure of $20 \mathrm{~mm}$. Hg. A mean of three readings was taken at the same time of day. Passive stiffness of one or other second metacarpophalangeal joint and volume of one hand were measured by methods previously described (Scott, 1960). Reactive hyperaemia was also measured in the arm (Pickering, 1933). In patients with Raynaud's phenomenon, serial recordings of digital skin temperature during a period of reflex heating of the trunk were made before and after the intravenous phase of treatment.

\section{Administration of EACA}

For intravenous use $250 \mathrm{ml} .0 .1 \mathrm{~g} . / \mathrm{ml}$. solution (containing $25 \mathrm{~g}$. EACA) were added to a bottle containing $300 \mathrm{ml}$. normal saline. Up to $50 \mathrm{~g}$. EACA daily werei given by infusion.

For oral use patients took either the granules contain- $v$ ing 50 per cent. EACA, a syrup containing $0.2 \mathrm{~g} . / \mathrm{ml}$., or윽 (because the latter was usually unpalatable) an aqueous mixture of the same strength. Dosage schemes forz every patient are shown in the Table (overleaf).

\section{Patients Studied and Results of Treatment}

The patients studied, together with the individua dosage of EACA and results of the treatment, summarized in the Table, which shows that EACA did not appear to alter the natural progress of the disease in any patient. In view of the negative results, details of the assessment criteria outlined $\stackrel{\mathbb{Q}}{\stackrel{\Phi}{ }}$ above are not given.

\section{Discussion}

In their first communication of the use of EACA in scleroderma, Rotstein and others (1963) gave $\frac{\varrho}{2}$ their patients $210 \mathrm{~g}$. of the drug intravenously over:7 days followed by $32 \mathrm{~g}$. daily orally (sometimes 3 . later reduced to $16 \mathrm{~g}$. daily). They reported that, in the patients who responded to therapy, the sclerodermatous skin became softer, oedema disappeared, $\mathrm{O}$ pigmentation lessened, joints became more mobile, and Raynaud's phenomenon improved. The sameo group (Rotstein and others, 1965) reported that the patients who responded to the treatment were thoseos showing the progressive stage of the disease, i.e.N oedema of the interstitial tissue and early frag-N mentation of the collagen and elastic fibres, whereas $\sigma$ tnose who did not respond showed hyalinization of the interstitial tissue. They suggested that the action of the drug was anti-inflammatory, anti- $\infty$ allergic, diuretic, or a combination of these.

Although our experience is smaller than that of 


\begin{tabular}{|c|c|c|c|c|c|}
\hline $\begin{array}{l}\text { Patient } \\
\text { No. }\end{array}$ & $\begin{array}{c}\text { Age } \\
\text { (yrs) }\end{array}$ & Sex & Clinical Details & Investigations & $\underset{\text { (Westergren) }}{\text { E.S.R. }(\mathrm{mm} . / \mathrm{hr})}$ \\
\hline 1 & 64 & $F$ & $\begin{array}{l}\text { Raynaud's phenomenon and stiffness of } \\
\text { extremities } 3 \text { yrs } \\
\text { Scleroderma involving hands and feet }\end{array}$ & $\begin{array}{l}\text { Barium swallow normal } \\
\text { Electrocardiogram normal }\end{array}$ & 8 \\
\hline 2 & 24 & $\mathrm{~F}$ & $\begin{array}{l}\text { Raynaud's phenomenon } 2 \text { yrs } \\
\text { Thickened and pigmented skin upper } \\
\text { limbs } 1 \mathrm{yr} \\
\text { Flexion contractures elbows } 6 \mathrm{mths}\end{array}$ & $\begin{array}{l}\text { Electrocardiogram: inverted } T \text { waves } \\
\text { Electromyogram: myopathy } R \text {. deltoid } \\
\text { Skin biopsy: Scleroderma }\end{array}$ & 5 \\
\hline 3 & 22 & $\mathbf{F}$ & $\begin{array}{l}\text { Tight skin on face and hands } 12 \mathrm{yrs} \\
\text { Raynaud's phenomenon } 5 \mathrm{yrs} \\
\text { Recurrent ulceration and healing of } \\
\text { finger tips, } 1 \mathrm{yr}\end{array}$ & $\begin{array}{l}X \text { ray hands: bone resorption from } \\
\text { terminal phalanges } \\
\text { Brachial arteriogram: organic occlusion } \\
\text { digital arteries }\end{array}$ & 23 \\
\hline 4 & 22 & $\mathrm{~F}$ & $\begin{array}{l}\text { Acute polyarthritis with oedema lower } \\
\text { legs and } 50 \mathrm{lb} \text {. weight loss in } 1949 \\
\text { Features of chronic dermatomyositis and } \\
\text { scleroderma with calcinotic nodu!es of } \\
\text { fingers }\end{array}$ & $\begin{array}{l}X \text { ray hands: bone resorption from } \\
\text { terminal phalanges and calcinotic } \\
\text { nodules }\end{array}$ & 10 \\
\hline 5 & 57 & $\mathbf{M}$ & $\begin{array}{l}\text { Raynaud's phenomenon and pigmenta- } \\
\text { tion skin } 2 \text { yrs } \\
\text { Pulmonary infections and dysphagia } 1 \mathrm{yr} \\
\text { Extensive scleroderma of skin }\end{array}$ & $\begin{array}{l}\text { Electrocardiogram: intraventricular con- } \\
\text { duction defect } \\
\text { Chest } x \text { ray: cardiomegaly, interstitial } \\
\text { fibrosis }\end{array}$ & 20 \\
\hline 6 & 67 & $\mathbf{M}$ & $\begin{array}{l}\text { Raynaud's phenomenon } 15 \text { yrs } \\
\text { Dyspnoea } 4 \text { yrs } \\
\text { Diarrhoea } 1 \text { yr } \\
\text { Extensive scleroderma of skin }\end{array}$ & $\begin{array}{l}\text { Skin biopsy: scleroderma } \\
\text { Other investigations confirmed involve- } \\
\text { ment of heart, kidneys, and small } \\
\text { intestine }\end{array}$ & 22 \\
\hline 7 & 53 & $\mathbf{F}$ & $\begin{array}{l}\text { Fatigue and muscular aching } 4 \text { yrs } \\
\text { Stiffness of extremities with Raynaud's } \\
\text { phenomenon and oedema } 2 \text { yrs } \\
\text { Tendon crepitus } 1 \text { yr }\end{array}$ & Skin biopsy: scleroderma & 15 \\
\hline 8 & 45 & $\mathbf{F}$ & $\begin{array}{l}\text { Greying of hair at age } 16 \\
\text { Bilateral lens cataracts removed at age } 28 \\
\text { Appearance of premature senility with } \\
\text { muscle wasting and tight shiny skin on } \\
\text { legs }\end{array}$ & $\begin{array}{l}\text { Werner's syndrome diagnosed } \\
\text { This patient was reported by Illis (1962) }\end{array}$ & 34 \\
\hline
\end{tabular}

Rotstein and his colleagues, we were unable to detect any improvement specifically associated with the drug in seven patients with scleroderma and one patient with dermatomyositis. The results were so unimpressive that a further trial was not undertaken.

We cannot say that EACA possesses no therapeutic action in scleroderma but, if it has any at all, this must be very slight or apparent in a small proportion of patients only. We doubt if it is, in fact, of any clinical use in this condition and statements of its beneficial effect should be treated with reserve unless substantiated by properly-controlled trials.

No serious toxic effects were encountered using these large doses, a fact which may be of interest to clinicians using EACA in the treatment of haemorrhagic diseases. None of our patients had any disorder of clotting as far as we know, but they were not investigated from this aspect. Case 1 had a transient episode of impaired colour vision and urticaria on the fourth day of infusion. The oedema in Case 7 increased during infusion. The only other adverse effects have been nausea and diarrhoea during oral therapy in seven of the eight patients, severe enough in Case 7 to make us discontinue the drug.

Other forms of treatment in scleroderma have been recently reviewed (Bywaters and Scott, 1965). Steroid hormones may suppress the more acute inflammatory manifestations of the disease, but nothing is known which will alter its variable course.

\section{Summary}

$\epsilon$-aminocaproic acid was not found to be of any definite benefit in seven patients with scleroderma and in one patient with dermatomyositis.

We are indebted to Professor E. G. L. Bywaters, who suggested this study, and to KABI Pharmaceuticals for supplying the various preparations of EACA.

\section{REFERENCES}

Bywaters, E. G. L., and Scott, J. T. (1965). "Progress in Clinical Rheumatology", edited by A. St. J. Dixon, p. 142. Churchill, London. 


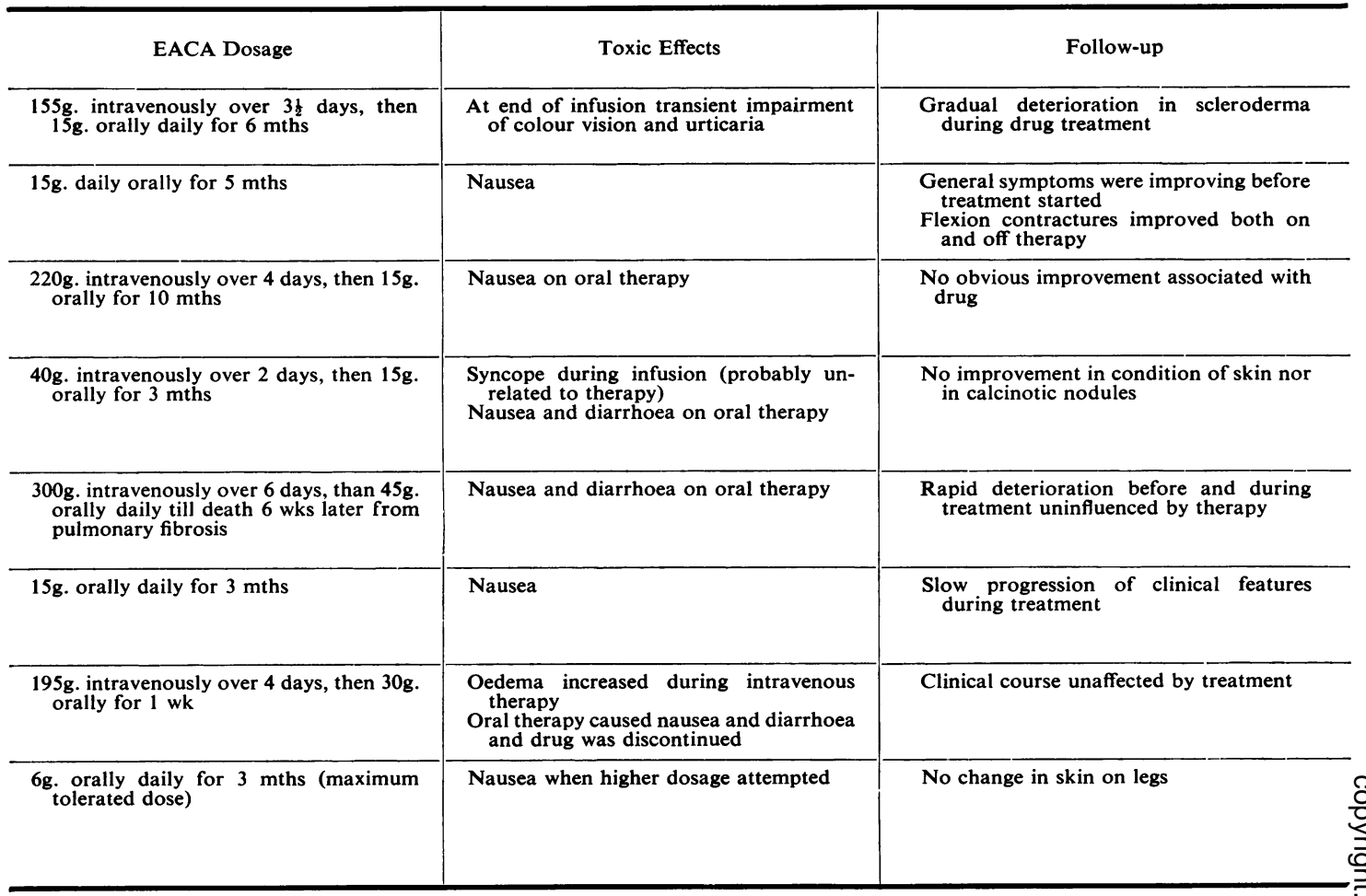

Illis, L. (1962). Postgrad. med. J., 38, 286.

Pickering, G. W. (1933). Brit. med. J., 2, 1106.

Rotstein, J., Gilbert, M., and Estrin, I. (1963). J. Amer. med. Ass., 184, 517 (letter).

—, Reiss, F., Lauriello, A., and Bourel, M. (1965). Arthr. and Rheum., 8, 465 (Abstract).

Scott, J. T. (1960). Ann. rheum. Dis., 19, 361.

Sherry, S., Fletcher, A. P., Alkjaersig, N., and Sawyer, W. D. (1959). Trans. Ass. Amer. Phycns., 72, 62.

Sweeney, W. M. (1965). Amer. J. med. Sci., 249, 576.
L'échec de l'acide $\epsilon$-aminocaprö̈que dans le traitement de la sclérodermie

\section{RÉSUMÉ}

Le traitement par l'acide $\epsilon$-aminocaproïque n'apporta aucun avantage défini à sept malades atteints de sclérodermie et à un malade atteint de dermatomyosite.

El fracaso del ácido $\epsilon$-aminocaproico en el tratamiento de la esclerodermia

Sumario

El ácido $\epsilon$-aminocaproico trajo poco beneficio definitivo a siete enfermos con esclerodermia y a uno con dermatomiositis. 